\title{
大腿骨骨頭骨折を伴う股関節後方脱臼骨折の治療経験
}

\begin{tabular}{|c|c|c|c|c|}
\hline 川 & 上 & 不二夫・河 & 合 & 伸 \\
\hline 城 & 戸 & 二・高 & 野 & 信 \\
\hline 白 & 石 & 元 $\cdot 大$ & 谷 & \\
\hline 加 & 藤 & 圭＼cjkstart彦 & & \\
\hline
\end{tabular}

山口労災病院整形外科

松岡彰・宮本 龍 彦

\section{Treatment of Posterior Dislocation of the Hip with Fracture of the Femoral Head}

by

Fujio Kawakami, Shinya Kawai, Kenji Kido, Shinichi Takano, Gen Shiraishi, Takeshi Otani and Yoshihiko Kato

Department of Orthopedic Surgery, Faculty of Medicine, Yamaguchi University, Ube, Japan

Akira Matsuoka and Tatsuhiko Miyamoto

Dipartment of Orthopedic Surgerry, Yamaguchi Rosai Hospital

We analyzed 10 hips of 9 patents with posterior dislocation and femoral head fracture. The patients ranged in age from 19 to 62 years (mean : 27), and were evaluated on average 2.4 years after the injury.

Hips classified as Pipkin type I had better clinical results than Pipkin type II, because type II hips had larger fracture fragments including weight bearing surfaces of the femoral head. Malposition of the femoral head fragments in Pipin type II needs to be correctly reduced and fixed by operative intervention.

Computed tomography derived before and after closed manual reduction may be necessary for treatment of posterior dislocation of the hip with femoral head fracture.

\section{はじめに}

大腿骨頭骨折は骨頭に強大な応力が動く外傷性股関 節脱臼に伴って発生する ${ }^{315)}$. 大腿骨長軸に沿って外力 が骨頭に伝わる際，股関節の肢位によりその骨折部は 異なってくる。

当科及び関連病院において大腿骨頭骨折を伴う股関 節後方脱臼骨折を 9 症例 10 関節経験しているので, 治 療成績とともに, その結果から本骨折の特徵, 治療上 の留意点, 手術適応について検討した。

\section{症例及び方法}

症例は, 男性 7 症例 7 関節，女性 2 症例 3 関節であ る. 受傷時年令は 19 才より 62 才, 平均 27 才. 受傷後 経過観察期間は 7 力月より 9 年 2 力月, 平均 2 年 4 力 月である. 受傷原因は，交通事故 6 症例 6 関節で， 3 症例がバイク走行中の衝突であった。そのうち 2 症例 が同側下腿の開放性骨折を合併していた。精神障害者 の飛び降り例では, 両側に股関節脱臼及び骨頭骨折が 認められた。

骨折型は Pipkin 分類によった。骨片が円鞄帯の付 
着する骨頭窩を含まないI 型は 2 関節, 骨片が骨頭窩 を含むII型は 4 関節，I 型またはII型の骨頭骨折に寛 骨臼後縁の骨折を合併するIV型は 4 関節であった. 頝 部骨折を合併するIII型はなかった。

CT 施行していない症例, 術後 7 カ月で現在免荷 中の症例を除く 8 関節について CT による骨片の大き さの評価を行ない, 日整会判定基準による成績と比較 した，骨片の大きさは骨頭中心を通る部位のスライス にて骨頭全周に対する比率として概算した。 このスラ イス部位は，骨頭窩のやや下方に位置する（図 1 ).

\section{結果}

IV型骨折は，I 型骨折に臼蓋骨折を合併したものが 3 関節と多かった。脱臼整復までの時間は, 同側下腿 開放性骨折を合併した 2 例で下腿の治療に気をとられ 整復が遅れていたが, 残りの 8 関節は 12 時間以内に施 行されており成績も概ね良好であった. 3 症例 3 関節 に骨頭壊死が出現しており, 62 才例では人工股関節置 換術が追加施行されていた。

CT による骨片の大きさは，I 型では，13\%，30\% であった， 2 例とも徒手整復のみであった． 37 才女性 例では骨片は頝部内側の関節包基部へ迷入し, 42 才男 性例では骨片は骨頭欠損部へ完全に還納した。ともに 成績は良好であった（表 1 )。

II型では，骨片はいずれもI 型より大きく，欠損部 は骨頭の 11 時の方向から $3 \sim 4$ 時までの前内側部で あった，良好な整復位が得られた例では成績は 100 点 であったが，骨片の尾側への転位が残存した例及び摘 出例では I 型より成績不良であった。

IV型では寛骨臼骨折に対してはすべて骨接合がされ ていた. I 型骨片を摘出した例では 97 点と成績良好で あったＩ型に合併した臼蓋骨折は寛骨臼後縁であっ たがII型に合併した臼蓋骨折は寛骨臼後上縁であっ た.

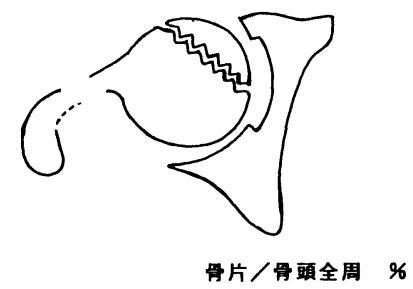

図 1

\section{考察}

骨頭骨折を伴う股関節後方脱臼骨折の発生メカニズ ムは特徴的である。臼蓋縁の後上方は骨頭より固く強 いが後方は骨頭より弱い ${ }^{3)}$. 膝届曲位, 股関節やや内転 位, 屈曲 60 度以下の場合, 大腿骨長軸方向に外力が働 くと骨頭は臼蓋後上縁で剪力をうけ骨頭骨折を生ず る. 骨頭窩が臼蓋後上縁へ向かう股位より伸展外転方 向では骨頭窩は内下方を向き Pipkin II型の，また屈 曲内転方向では骨頭窩は後方を向き Pipkin I 型の骨 折がおこりやすい.したがって II 型の骨片は荷重面を 含み大きくなるＩ型では骨頭窩より下方にあり荷重 面をはずれ小さくなる1)5). また屈曲位が強くなると Pipkin I 型の骨片とともに, 脱臼時, 骨頭より弱い臼 蓋後縁の骨折をおこしやすい. IV型は I 型骨片に臼蓋 後縁骨折を合併したものが多いであろうと推測でき る.

I 型は骨片も小さく荷重面も少ないため成績は良 い. 徒手整復後, 骨片の位置・可動域制限の有無によ り摘出術で対応できると考えられた，IV型の多くは I 型骨片に臼蓋後縁骨折を合併したものであった，臼蓋 骨接合・骨片摘出術により成績は良好である，II型は 骨片が大きく荷重面を含むため，より正確な整復が望 まれる. II型における摘出術の結果は 1 例において不 良であった．整復不良の場合は観血的整復固定術が行 なわれるべきである ${ }^{1) 2}$. 手術適応は自験例からは，(1) 骨片が脱臼整復障害因子となっている場合，(2)脱臼が 整復されても骨頭骨片の下方への転位が残っている場 合，(3)骨片が有意に大きく整復されても運動により転

表 1 治療成績

\begin{tabular}{cccccc}
\hline \hline type & \multicolumn{2}{c}{ case } & 骨片処置 & 骨片/骨頭全周 & 成績 \\
\hline I & 37 & F & & $13 \%$ & 90 点 \\
& y. o. & & & \\
& 42 & M & & 30 & 97 \\
\hline \multirow{2}{*}{ II } & 19 & M & 骨接合 & $33 \%$ & 100 \\
& 27 & M & 骨接合 & 33 & 89 \\
& 27 & F & & 33 & 88 \\
& 36 & M & 摘出 & 40 & 73 \\
\hline \multirow{2}{*}{ IV } & 27 & F & 摘出 & 25 & 97 \\
& 21 & M & 骨接合 & 75 & I + A F \\
& & & & II + A F \\
\hline
\end{tabular}

AF:Acetabular Fracture 
位をきたし，骨片の固定を考慮する場合，であった。

CT は整復前に臼蓋骨折の存在, 高位, 程度を知るの に役立つだけでなく, 整復後に行うことにより臼蓋関 節内小骨片の存在を確認できる4)ほか, 健側との比較 により骨片の大きさ，部位の把握や骨折型の決定にも 有用であり，行うべき検査であると考えられる。

$$
\text { ま と め }
$$

1. 自験例 9 症例 10 関節について, 主として骨折型, 骨片の大きさ，治療成績について検討した。

2. IV型は I 型骨折に臼蓋後縁骨折を合併したもの が多い.

3.II型において整復不良例では手術的治療がすす められる。

4. 徒手整復前及び後の CT は有用であり必須のも のと考えられる.

\section{文献}

1）東 博彦・他：外傷性股関節脱臼に伴う骨頭骨折. Hip Joint, $8:$ 100-107, 1982.

2) Butler, J. E. : Pipkin Type II Fracture of the Femoral Head. J. Bone and Joint Surg., 63A : 12921296, 1981.
3) Davis, J. B. : Simultaneous Femoral Head Fracture and Traumatic Hip Dislocation. Am. J. Surg., $80: 893-895,1950$.

4) Hougaard, K. et al. : Computerised Tomography After Posterior Dislocation of the Hip. J. Bone and Joint Surg., 69B : 556-557, 1987.

5）轲田典夫・他：骨頭骨折を伴う股関節脱臼骨折の長 期成績. Hip Joint, 8 :137-146, 1982.

\section{質 問鹿児島市立病院 谷口 良康} 大腿骨骨頭骨折の骨接合の材料として，私達は，バ イオセラム, サファイヤスクリューを使用，抜釘は行 っていない. 接合材料について, 如何お考えですか.

$$
\text { 解 答 山口大学 川上不二夫 }
$$

固定法について

呈示した症例は 9 年前のものであり, 通常の screw を使用しましたが，最近ではサファイヤスクリュー等 の固定材料を使用している. 免荷の根拠 合併症等が大きく危惧される場合は，やはり長期間 の免荷を指示する.

通常は，短期間の免荷でよいと考えます。 